\title{
Contributions to the study of teachers'associativism
}

\section{Contribuições ao estudo do associativismo docente ${ }^{1,2,3}$}

Libânia Nacif Xavier (i)

\begin{abstract}
(i) Universidade Federal do Rio de Janeiro - UFRJ, Rio de Janeiro, RJ, Brazil. http://orcid.org/0000-0003-4422-2118, libanianacif@gmail.com.
\end{abstract}

\begin{abstract}
:
By presenting useful references to develop the study of teachers' associativism from the socio-historical point of view, the article addresses questions that have become central to the development of our research. It is divided into seven topics. The first topic underlines the contributions of Social History and the second brings attention to the contribution of theories of social movements and it's traditions of research. The third topic focuses on the contributions of political science and the next topic addresses sociological studies of the labor movement. The fifth topic presents some results of the research that bases the present article, while the sixth comments two articles that analyze the production on the subject. The seventh and last topic emphasizes the issue of teacher identities. We conclude by reaffirming the potential of interdisciplinary dialogue to study the theme.

Keywords: associative teacher, history of education, educational research
\end{abstract}

\footnotetext{
${ }^{1}$ Financial support: Conselho Nacional de Desenvolvimento Cientifico e Tecnológico (CNPq)

${ }^{2}$ References correction and bibliographic normalization services:: Aline Maya (Tikinet) - revisao@tikinet.com.br

${ }^{3}$ English version: Viviane Ramos- vivianeramos@gmail.com
} 


\title{
pro.posições
}

http://dx.doi.org/10.1590/1980-6248-2018-0013

$e$-ISSN 1980-6248

\begin{abstract}
Resumo:
Apresentando referências que considera úteis para desenvolver o estudo do associativismo docente do ponto de vista sócio-histórico, este artigo aborda questões que se tornaram centrais no desenvolvimento de nossas pesquisas, sendo dividido em sete tópicos. O primeiro sublinha as contribuições da história social, e o segundo confere atenção à contribuição das teorias dos movimentos sociais e das tradições de pesquisa a estas associadas. O terceiro tópico focaliza as contribuições da ciência política, e o item seguinte aborda os estudos sociológicos sobre o movimento operário. O quinto tópico apresenta alguns resultados da pesquisa que embasa este artigo, enquanto o sexto comenta dois balanços que analisam a produção sobre o tema. O sétimo e último tópico atribui ênfase à questão das identidades docentes. Concluímos reafirmando a potencialidade do diálogo interdisciplinar para o estudo da temática.
\end{abstract}

Palavras-chave: associativismo docente, história da educação, pesquisa educacional

\section{Contributions to the study of teachers' associativism}

Presenting some theoretical references useful to develop the study of teachers' associativism, from a sociohistorical perspective, this article approaches issues that have become central in the research development on the theme (Xavier, 2013a). The research aimed to understand the impacts of different teachers' associativism experiences, related to career configuration; State policies; organization and functioning of school; as well as strategies of teaching legitimization. This article starts by problematizing the term teachers' associativism, reminding that the choice of relevant questions has an array of theoretical references from different subject fields. Within those, we highlight references from history, sociology, and political sciences, especially the approaches integrated to the field of social movement and collective action theories.

In the first topic, the goal is to highlight the contributions of social history to the study of the theme, and to evaluate the perspective of its study, developing beyond the memory of their feats and the historic registries of certain associations. The second topic gives attention to the contribution of social movement theories and the research traditions associated to them. 


\section{pro.posıções}

$e$-ISSN 1980-6248

http://dx.doi.org/10.1590/1980-6248-2018-0013

The third topic focuses on the contributions of political science, while the fourth highlights the possibilities of sociological studies on workers' movement, signaling possible interferences on the opposition between old and new trade unionism in the production on the theme. The fifth topic presents some research results which base this article, while the sixth resumes contributions of studies developed by Brazilian researchers in the last 30 years, some of them analyzing the production on the theme, while others highlighting the question of teacher identities amidst the engagement (or the distancing) of union fights. The seventh and last topic emphasizes the issue of teacher identity. We conclude by reaffirming the possibilities of interdisciplinary dialogue when studying the theme.

\section{Contributions of social history}

We understand that the term teachers' associativism involves all sorts of teachers' collective organizations to defend their interests in different spheres of social life, including professional, political, social, and cultural dimensions. It can also encompass the study of union organization or teachers' associations of professional and scientific characteristics, as well as refer to associations of different characters, such as philanthropic, religious or political, emancipatory, assistentialist, or that reproduces the dominant status.

About the origin of the associations, it is fair to establish their emergence in the confluence between an unbalance of social control and a desire for change. About this, an analysis based on theoretical and methodological premises gives us fertile tools for a more dynamic and contextualized vision of teachers' associative movements. In his $\mathrm{PhD}$ thesis, Daniel Lemos (2011) analyzed the associative movement among Brazilian teachers in the city of Rio de Janeiro, which was then the court capital in the $19^{\text {th }}$ century. Based on official documents, news published in papers and in the pedagogical press, besides documents such as petitions, manifests, and similar material, the author found registries of nine teachers' associations ${ }^{4}$. This has allowed him to understand the genesis of these associations, but not to know exactly which was the first or the oldest, as this would not have much contribution to the problematization of the subject studied. In fact, what he aimed was to see the variety of

\footnotetext{
${ }_{4}^{4}$ These nine associations would not be the first nor the only ones, as clarified by Lemos (2011), but which could be identified by the documents researched.
} 


\section{pro.posıções}

$e$-ISSN 1980-6248

associative forms, its relations to the broader social context, their connections to singular individuals, as well as how those expressed themselves regarding professional (even official) practices in course.

With this approach, Lemos (2011) draws a dynamic panorama of diverse teachers' association, aiming to perceive them amidst the pedagogical debates of the time, and in relation to the workers' movements of other professions. We agree with the author regarding the importance of observing teacher associativism beyond the relations established with the constituted powers, enriching the analysis with the observation of its relations with other social movements. However, without forgetting the other dimensions intersecting associative experiences, we should highlight the pertinence of observing with well-adjusted lenses the relations established between collective movements and the official politics, having in mind the own nature of this type of action/organization.

As observed by the historian Jean-Pierre Rioux (1996), in the classic article entitled "The association in politics", associations assume multidimensional roles and, often, ambiguous, because, at the same time, they oppose and participate, grant services and defend ideas, substitute the public sector in crisis and exert counterpowers, constituting a place of emergency and conservation of sociabilities, and, at the same time, activating mechanisms of power dispute and search for new legitimizations. The researchers on the topic present different approaches according to the specific characteristics of social movements and the collective actions (and associations) analyzed, classifying them as contestation or consensus (Rioux, 1996), as revolutionaries or reformists (Hobsbawm, 1982, 1987), among other possible classifications.

As it is known, the pression exerted by collective actions - orchestrated by already established associations or by groups that do not aim institutionalization-impact not only the individual experience of teachers, but also interferes in the form of the professional career, leading to a change on the collective. It also acts on the management of policies from power instances connected to State bureaucracy. In this sense, it is relevant to analyze the empirical field defined by the type of associativism and the collective actions of a professional group, understanding their logic of internal organization (amongst teachers) and external interlocution, with instances of power acting on the context in question, as well as the public opinion ${ }^{5}$.

\footnotetext{
${ }^{5}$ The term public opinion reminds us of the relation of newspapers (and other media, such as TV) in the formation
} of social consensuses and highlights the existence of a civil society, apart from the State. In this perspective, the 


\section{pro.posıções}

e-ISSN 1980-6248

http://dx.doi.org/10.1590/1980-6248-2018-0013

Throughout the period of Estado Novo (1937-1945), the government established a strong control over any initiative of collective organization, restricting free association, especially among public workers. The brief democratic interval, from the end of the 1940s to the beginning of the 1960s, had a movement of protests of high-school teachers in the city of Rio de Janeiro which reverberated in the press. The press opened a big space for the manifestation of privateschool owners, who blamed the government for teachers' dissatisfaction, which was motivated, according to the owners, by the little official resources given to those schools ${ }^{6}$.

The military regime, established in 1964, inhibited the collective actions of teachers as well as the right of free association, a situation that continued until the democratic transition, which marked the end of the 1970s and the whole 1980s. This new context favored the creation of public teachers' unions, which joined the fights against the military regime and for the democratization of society. A great part of public teachers' unions - in different states and cities of the country- has structured themselves according to a model of organization that had, as the main target, confronting the State power aiming to reduce the mechanisms of government control and increase the margins teachers' professional and political autonomy.

When adopting the history point of view to study the different forms of teachers' associativism, we tend to consider the collective mobilizations as indicators of social change processes, as expressions of the desire to rationally interfere on teaching policies, scientific development and, above all, the valuing of professional career. Therefore, the aim is to understand how the constituted and intermediary powers interact; the institutions inherited and the new aspirations; the collective ideals and the singular tensions in the empirical contexts analyzed. In this perspective, the observation of associations as a whole and in interaction, as well as articulating them to leadership trajectories can suggest research and observation pathways that would not be visible if taken the individual, or a group, or a sole organization as an object of study.

focus is on the debate of opinions that the journalistic press expresses, either in a role of control, or as a legitimizer of state institutions, interfering in the public debate.

${ }^{6}$ About this, see: Vicentini and Lugli (2009). 


\section{pro.posições}

$e$-ISSN 1980-6248

http://dx.doi.org/10.1590/1980-6248-2018-0013

The variation of observation scales, as proposed by Revel (1998), constitutes a research procedure that allows an analysis of relations and contact points between the individual and the collective; spontaneous actions and organized forms of association; the behavior of the State and its interaction with collective movements, allowing us to perceive such processes in a dynamic way and less unilateral and fatalist. The articulation between the more general political context and the advancement of association forms demanded the attention of studies developed in the scope of political sciences. We believe that, through these, it would be possible to broaden the theoretical and methodological procedures useful to the understanding of the relations among movements, teachers' associative formats, and established powers. Having in mind the condition of public workers as one of the identity markers of this group, the relations with the State and the bureaucratic representations related to teaching have taken a relevant space in the research, as well as the repertoire of actions mobilized by teachers in their political and professional fights.

In the next topic, we intend to reflect in what measure the understanding of collective teachers' movements can gain in extension and depth, when dialoguing with the studies seen as key to social movement theories.

\section{Contributions of social movement theories}

On this topic, the contributions of Maria da Glória Gohn's (2008) studies are unavoidable. In the book entitled Teorias dos movimentos sociais: paradigmas clássicos e contemporâneos (Theories of social movements: classic and contemporary paradigms), the author presents a bold synthesis on the research traditions that have been guiding the studies of collective social movements. From this synthesis we highlight indications that can help us confirm or refute some orientations used in the development of studies on this theme. The first of them helps us to identify the main concerns, as well as the instruments of analysis used by these research traditions. The author identifies the main axes to approach the theme, such as: the NorthAmerican paradigm and the theories of resource mobilization; the European studies with a Marxist paradigm and the paradigm of new social movements (NSMs); the Latin-American studies and the approaches on political opportunities structures. We will now characterize these paradigms. 


\section{pro.posıções}

http://dx.doi.org/10.1590/1980-6248-2018-0013

$e$-ISSN 1980-6248

Among the European studies, the author highlights the Marxist approach and the NSMs, each encompassing a series of explanatory theoretical lines of thought. The Marxist approach focus on the study of global historical processes, in the existing contradictions and social class fights, electing as basic analytic categories the notions of collective experience, field of forces, class interests, popular organization, political project, political culture, urban contradictions, urban social movements, among others.

On its turn, the NSMs paradigm starts from more conjunctural explanations, located in the sociopolitical scope or the microprocesses of everyday life, making the necessary focuses to observe the politics of new social actors. Its categories and basic notions are culture, identity, autonomy, subjectivity, representations, political interaction, collective identity, collective representations, solidarity, social networks, and others.

The North American paradigm has, in its different versions, explanations centered more on the structure of the organizations called sociopolitical and economic systems, choosing as basic analytical categories the notions of system, collective organization, organizational behaviors, and social integration. From these categories, several other concepts are developed, such as the notion of cultural deprivation, rational choices, resources mobilization, institutionalization of conflicts, cycle of protests, frames, and political opportunities. Its main explanation base is that social movements should be approached as groups of interests and, therefore, analyzed under the organizational logic. The most important variable in its analysis are the resources: human, financial, and infrastructure, to which are given a decisive influence to the emergence of social movements.

Through this perspective, the conclusion is that the movements appear when political opportunities to collective actions are structured, and when facilities and leaders are available. The movements also structure everyday life according to the stock of resources they have, mainly economic, humans, and communication (Gohn, 2008). Regarding the characterization of the North-American paradigm, we highlight, based on Gohn's (2008)synthesis, the contributions of two authors and their influential works: Anthony Oberschall (1973), with Social conflict and Social movement, and Charles Tilly (1977), with From mobilization to revolution. Anthony Oberschall points out that the collective behavior and the social movement have been shaping the contemporary institutions and will probably continue to do so in the near future. He reflects, however, on the difference between these two modes of action: the collective behavior, as 


\section{pro.posıções}

$e$-ISSN 1980-6248

http://dx.doi.org/10.1590/1980-6248-2018-0013

expressed through crowd manifestations (pickets, public manifestations, public petitions, and even riots), is episodic and uncommon; on the other hand, the social moments are, in a large scale, collective efforts looking for changes or resisting them.

Both alter people's lives. In Oberschall's (apud Gohn, 2008) perspective, the movements do not appear as a result of abrupt or dramatic events, but due to the increase of experiences taken as unjust and unequal, and that can be stimulated by individuals increasing their capacity to act collectively ${ }^{7}$. Thus, emphasizing the importance of certain leaderships in the processes of strengthening of a profession and of teachers' associativism does not necessarily mean that the researchers are restricting the analysis of collective movements to the contribution of a single person. On the contrary, often, this type of approach can potentialize the perception of the interactions among groups and union organizations, led by the private initiative or the State, as the individual studied moves in different groups, institutions and instances of power. To follow their itineraries through these spaces can tell us more about the collective fight and their interactions and appeals, than if we were limited to focus on the creation and development of a single collective organization

We know there are less rational unfoldings, but that result in tactic agreements and configure a way that individuals and groups deal with the unbalances and the political and social tensions affecting them. In the work From mobilization to revolution, Charles Tilly (1977) presents a retrospective of collective action theories and aims to understand how the great structural changes affect the prevailing notions of this type of action, emphasizing the role of beliefs and ideologies in the stimulus to collective mobilization. In this work of Marxist perspective, the author bases himself on the studies of Eric Hobsbawm and the historians from the Annales School, taking the category of long duration to demonstrate how communal solidarity interferes on voluntary associations. He applies the theory of Resource Mobilization to classify the types of mobilization into offensive and defensive, and analyzes the relation of organized groups in collective actions with the elites and the results of this process in political terms, emphasizing the State role and the changes that took place in the institutionalized political system.

\footnotetext{
${ }^{7}$ In this perspective, the dissatisfaction and solidarity act as the main factors in the analysis of the social conditions which provoke the emergence of collective movements. In fact, for them to happen, a lot of organization work is needed, tending to internal normalization regarding regulations and a centralization of power aiming the creation of an authority line (Gohn, 2008).
} 


\section{pro.posıções}

http://dx.doi.org/10.1590/1980-6248-2018-0013

$e$-ISSN 1980-6248

Tilly (1977) tries to establish comparisons among different historical periods, highlighting the repertoire of collective actions of each one and analyzing the reason of the decline of collective actions repertoire and the emergency of others. Applied to the study of teachers' associativism, the long duration perspective allows the establishment of union organization patterns, as well as collective actions in a contextualized way, that is, interacting with the political and intellectual ambivalence of the periods studied, allowing a broader and comparative analysis, in time and space. Thus, making more visible the permanences and changes operated in the patterns of organization and fight.

From the debate between the European and North American theoreticians, Gohn (2008) identifies a new approach that predominated in Latin America and in which the main emphasis is on the political process of mobilizations and the cultural bases that sustain them. The NSMs school highlights the process of construction of movements' political identities and their potential to resist (especially culturally). According to the concepts of Marxist paradigm, the issue of political power is central. In North America, the theories resulted from the discussions in the 1980s also emphasized the political process, especially the power game between civil society and governmental structures, resulting on a game of political opportunities structure (POS), an approach that will be deepened in the studies of political science.

\section{Contributions from political science}

As observed by McAdam, Tarrow, and Tilly (2009) in an article offering contributions to map the political confront, the social movements developed within the limits established by prevailing structures of political opportunity. That means that repression and facilitation of revindications by public authorities, the presence of potential allies, rivals, or enemies significantly affect any pattern of confrontation in the political system. However, it is important to highlight that, in a longer period, the actions of social movements also alter the structures of opportunities, mainly when contributing to changes in the known ways to revendicate, the forms of repression and facilitation by authorities and established political figures. In the research we conducted (Xavier, 2013a), such indications appeared to be a fertile ground to understand the dynamics that permeated the public manifestations of teachers' syndicates in the decline of the 


\section{pro.posıções}

$e$-ISSN 1980-6248

military regime (which lasted from 1964-1985) and democratic construction ${ }^{8}$. In the case of Rio de Janeiro, a march, that claimed more aggressive watchwords and was faced by a strong policing, returned to public in another occasion with the teachers laying flowers on the feet of police officers. The contrast of the image printed on the newspapers - teachers with flowers facing police officers with shields, helmets, and batons - forced the government to decrease the tone of their force demonstration in the following manifestations, avoiding the loss of support by the public opinion. This demonstrates how symbolic actions - in this case, the confrontation and convincing of public opinion for a cause- are dynamic, mobile, and interactive.

Therefore, we considered that the concept of POS can be fertile to help the analysis of relations between teachers' associative movements and the transformations that took place in the State. Even considering as a base the Gramscian concept of State, integrated to the civil society, we understand that the fractures in the power balance occupy a certain importance to comprehend the factors that have contributed to the emergence of teachers' collective mobilization/organization.

As we have shown in a previous publication (Xavier, 2013b), the political opening, as well as the tendency of repression by the State influenced the appearance of collective action in civil society. The democratic transition of the 1980s- 1990s in Brazil is, on itself, an example of how teachers and others professions intensified the pressure on the military governments aiming advancements, in relation to the interests of a professional category as well as the decline of authoritarianism, and the development of democracy.

\footnotetext{
8 Among the many aspects that mark the category of Brazilian public workers in the military period, Ferreira e Bittar (2006) points out its numerical growth in parallel to its income reduction. Pressed by the quick fall in its living and work standards, the teachers developed, according to the authors, a political awareness that integrated them to the tradition of workers' fights - in the frame of union expression aiming to convert their needs into economic proposals through concrete political fights. These factors would have contributed to give Brazilian public teachers, at the time, an identity opposed to the regime itself.
} 


\section{pro.posıções}

http://dx.doi.org/10.1590/1980-6248-2018-0013

$e$-ISSN 1980-6248

Thus, the reconfigurations in the political system presented themselves as opportunities to rehearse changes, attempt alliances, earn rights. We should consider, however, the identity mechanisms that unleash this process, as they depend on the ability of the actors and their leaders to identify the events that indicate a possible opportunity. Such identification can derive from a declaration of authority of the government or the manifestation of other groups pointing to the existence of political opportunities, promoting a game of readings, and initiate a snowball of collective movements and manifestations.

Analyzing the Portuguese case, Cerezales (2003) alerts to the fact that the use of POS notion should be careful and one should not trust the apparent transparency of its explanatory mechanisms, whose validity should be circumscribed to State forms of public space development. Besides, we should note that there is no unidimensional relation between the level of openness of the political system and the social movements, as the system can be selective and combine openness to a certain type of actor, creating, at the same time, obstacles to others.

As summed up by the author (Cerezales, 2003), POS has four dimensions: (i) the level of openness (or closeness) to the political system; (ii) the stability or instability of the elites' alignment; (iii) the presence and characterization of aligned elites; (iv) the ability and propension of the State for repression. If we stick to these dimensions, it is possible to perceive that the movements spread taking advantage of opportunities, but, through their actions, force the realignment of different actors in the political community. They forge and break alliances and, in this process, can promote the appearance of new opportunities to themselves and other social movements. Cerezales (2003), finally, adds that the forms and contents of social and political fights can act as the drive of State restructure and its many bodies, they can also condition the format and the content of productive restructures.

In other words, as the social movements interfere in the structure and the functioning of State, the dialogue established through confrontation and possible negotiations also interfere in the guidance of social movements, creating a game able to rule the repertoire of social movements and the answers of governments. Based on these observation, we raised the hypothesis that the moments of political rupture - particularly the process of reestablishment of democratic life in many European and South American countries- provided advancements in the construction of a more autonomous teacher identity, allowing the construction of new 


\section{pro.posıções}

http://dx.doi.org/10.1590/1980-6248-2018-0013

$e$-ISSN 1980-6248

power relations, inside and outside the school institutions, sometimes confronting and other negotiating with governmental instances?

We believe that we need to understand teachers' associative movements in relation to the socioeconomic conditions in which they took place and in tune with the main cultural practices of the profession. To do so, we must observe the values and behaviors, and watch for innovations and concepts that they share regarding the social and political role of the profession. Thus, to understand the history of teaching through a social movement perspective implies to prioritize the protagonism of teachers in guiding their own history and the interactions of the group with political cultures predominant in specific contexts. In this perspective, the nomenclature used to call each context has, in itself, a point of view on politics and teaching that needs to be clarified. Therefore, we should pay attention to the vocabulary used in the contexts of fights analyzed, confronting the terms so-called natives with those used in the present and the contexts familiar to us.

It is also relevant to contextualize the theoretical references we are taking as analytical support, considering that they are marked by the political debate (not only theoretical) in which they were produced, as it is clear in the academic production on the workers' movement in the 1970s-1980s, strongly marked by the contradictions between the emerging syndicalism and the fights for democratization in societies under authoritarian governments, and the old ways of union organization, marked by clientelist and ownership relations.

\footnotetext{
${ }^{9}$ About this, it would be important to problematize the terms democratic transition and redemocratization, Analyzing the theories of democratic transition in force during the 1990s, Avritzer e Costa (2004) highlight the relevance of studying the model of relationship between State, political institutions, and society, extending the focus of the democratization process - in this case, the moment of transition- to a permanent process and never entirely finished of popular sovereignty, a primordial element to substantiation of democratic regimes.
} 


\section{pro.posições}

http://dx.doi.org/10.1590/1980-6248-2018-0013

$e$-ISSN 1980-6248

\section{Contributions of workers' movement studies}

The workers' movement was a prime object in History and Social Sciences, considering the political weight involving the study of the theme, because it allows, at least theoretically, to articulate analytical possibilities produced in the academic field with the expectations of participation the power games in social lie. The production on the theme is vast, approaching issues of different natures, and involving varied theoretical-methodological contributions. Therefore, we will have a very specific focus and will use analyses already done by specialists in the topic, dialoguing, in particular, with the analyses developed by Perruso (2009) in the book Em busca do "novo": intelectuais brasileiros e movimentos populares nos anos 1970-1980 ( Searching the “new": Brazilian intellectuals and popular movements in the 1970s-1980s).

In this work, the author approached the studies developed in the 1970s and 1980s on urban social movements and, especially, the syndicalist movement in the scope of Brazilian production (Perruso, 2009). Among the highlights, he quotes the pioneer work of Leôncio Martins Rodrigues, published in 1974. He mentions that the work already pointed out the differences between the new and old unionism, using the notion of autonomy to show that, in Brazil and Latin America - contrary to European and North American societies- the workers were framed by the State, having their capacity and freedom of action and mobilization reduced. The same author argues that, in developed countries, unionism would have faced a period of conflicts, after which there was a weakening of its radical classist guidance, with the predomination of a syndical perspective more concerned with the workers' participation on strictly factory issue.

According to Perruso (2009), this perception was deepened by authors such as José Álvaro Moisés, Maria Hermínia Tavares de Almeida, Eder Sader, and Wilma Mangabeira. Based on the study of these authors, he sums up the great lines that differentiate and oppose the two terms. The old unionism would be characterized as an heir of a populist political practice and a corporativist syndicate structure, operating strategies to obtain material benefits and social projection based on a close association with the State and the elites, that is, at the expense of its weakness as an organization and social movement, becoming more and more bureaucratized, oligarchic, and less representative. Together with this definition of the old, the authors mentioned also described what would be the new unionism, identified by characteristics such as the ability to integrate economic, social, and political issues in their fights, gaining importance 


\section{pro.posıções}

http://dx.doi.org/10.1590/1980-6248-2018-0013

$e$-ISSN 1980-6248

amidst the popular classes; autonomous and independent, born outside the State scope; challenger of corporative legislation and the syndical structure, including in the work justice and the bureaucratic and assistentialist syndicates, defending the unrestricted right to strikes and unionism freedom.

Such cleavage is due to a repertoire that allows the classification, hierarchization, and differentiation of collective mobilization models within the same associative modality: the union. Likewise, it allows us to identify to what point the analysis on collective movements articulate themselves in the context they are developed, expressing and intensive circulation of models - practical and theoretical - in a movement that goes beyond the national and disciplinary frontiers, as well as institutional structures. One of the consequences of this hierarchization in the scope of theoretical production was the prevalence of studies that prioritized the focus of analysis on the associations framed on the so-called new unionism, relegating the study of union associations of corporativist, patrimonialist, or assistentialist nature to the background.

Considering these contributions and reservations, we aimed to bring to the center of our research interests the observation of different forms of associative organization interacting in the period analyzed. The sources consulted, later confirmed in recently defended thesis, showed that some associations were incorporated to the new unionism (Braga, 2017), while others unfolded from unions that emerged in the period (Andrade, 2017). It is important to highlight in this debate that the same old associations, often, offered support to the new unionism, be through the participation of some of their leaders in joint actions, be it through the support and exchange established from each organization.

Having in mind these contributions, our researches show some relationship patterns between teachers' collective actions and the impacts of these experiences in their professional trajectories, calling attention to the importance of the issue of teachers' identity, as we will detail next. 


\section{pro.posições}

http://dx.doi.org/10.1590/1980-6248-2018-0013

$e$-ISSN 1980-6248

\section{Results on a research on teachers' associativism}

Considering the teachers as the protagonists of their own history, the research that based this article followed and tried to understand the strategies and the models of teaching associatiavism established in contexts marked by the combination between the restoration of political and social mobilization and the disorganization ( or limitation) of State control, aiming to perceive their developments on an individual and collective point of view ${ }^{10}$.

The theoretical references of different disciplines here suggested were efficient, in our opinion, to answer relevant questions, indicating us the individual bounces of the union experience in the definition of identities and professional trajectories. Through this path, there was the unveiling of a more multifaced and dynamic career than we could have perceived through the "naked eye", understanding, through the individual trajectory studied, certain reorientations in the teaching career, demonstrated on the changing among institutions, teaching levels, and management positions in schools, in bureaucratic instances, etc. We could also see how much the associative experiences contribute to empower individuals, groups, educational institutions, especially through the capability of a broader vision on the profession itself, as well as the policies that affect them, their own professional potentialities, and collective leadership, in some cases. (Lélis \& Xavier, 2010).

We should also notice that the perception regarding the conflicts established between unions and school representatives, be through the dispute to control of school daily life and the influence on the professionals, or through the different perspectives expressed by certain groups and leaders regarding the role of the support bases - the non-unionized teachers, the school staff - as a perspective of expansion and strengthening of the influence of unions on teachers (Xavier, 2014).

In some schools, the experiences of participation in the process of democratic construction put into practice by teachers who also had some leadership on pedagogical changes and political ones, promoting the participation of the faculty in the public debate, ended up adopting new patterns of organization and working, more democratic and participative, leading

10 We refer to a recent period: the 1970s and 1980s, when many countries in Latin America (such as Brazil, Argentina, Chile, and Uruguay) and Europe ( as Portugal and Spain) saw the fall of authoritarian regimes in power until the end of the 1970s, followed by processes of democratic (re)construction in these countries, which had their processes of political rupture in the mid and late 1970s and developed their mechanisms of democratic construction and stabilization through the whole 1980s. 


\section{pro.posıções}

$e$-ISSN 1980-6248

http://dx.doi.org/10.1590/1980-6248-2018-0013

to the creation of reference groups among these professionals, as well as creating new ways of resisting the lack of governmental support to stabilize and continue the democratic pattern of school participation they had experienced (Xavier, 2013a).

At last, we have to highlight the interesting games of interaction between the actions organized by teachers and the answers of the official powers, showing how the State and workers, in this case the teachers, established their agendas of fight and public demonstrations trying to unbalance and answer one another, having the daily press as a relevant actor in the repercussion - positive or negative - of the fights and actors in dispute (Xavier, 2011). Moreover, we can say that the press role, researched in different moments in the history of teachers' political manifestations in Rio de Janeiro, had little variation on the way of reporting teachers' strikes from the 1950s to the one in the 1970s and 80s. Expressing the social panic, referred by Adorno (1995), faced by the demonstrations of rebellion by the teachers, the papers, as expected, condemned the strikers. Disqualifying the strikes for their political-party character, the papers called the teachers gazeteiros (a term that can be used to indicate a student that skips classes), accusing them to be more concerned about their economic (and political party) interests than their mission to form the students, having in mind the project of national salvation ${ }^{11}$.

As observed by Lawn (2001), teachers' identities suffer innumerous interventions in their elaboration process - the State, through laws and regulations; the press, by the way they treat teachers' public image; school managers, by how they relate with the work of those professionals, etc. The games of intervention and identity negotiation are, therefore, extremely relevant to understand the professional statute of teachers and, thus, became a relevant concern in the researches on the theme, as we will indicate in the following section.

\footnotetext{
11 The researched newspapers were: O Correio da Manhã (1955-1957); Diário de Notícias (1955-1957) and Tribuna da Imprensa (1955-1957); as well as O Globo (1978-1979 and 1988-1989) and Jornal do Brasil (1978-1979 and 1988-1989).
} 


\section{pro.posıções}

http://dx.doi.org/10.1590/1980-6248-2018-0013

$e$-ISSN 1980-6248

\section{The issue of teachers' identities}

When presenting his contribution in the I Seminar to Discuss Researches and Establishment of an International Network of Reasearchers on Associativism and Unionism of Education Workers ( in Portuguese, Rede ASTE) ${ }^{12}$, Sadi Dal Rosso (2009) called the attention to the importance of articulating the research on teachers' unions and the studies about unions in general, seen the collective action of teachers as part of the ensemble of union activities, but also considering its relative autonomy, considering the specificities of their work. The author also observes that, comparing to other workers, the teaching union was institutionalized later due to objective reasons, such as the fragmentation of this professional category and the strict control submitted by public agents. He adds the subjective nature of the work, focused on the socialization of the new generations and the transmission of accumulated cultural heritage, therefore, involved with activities of intellectual and affective character.

These observations lead us to reflect on the different theoretical supports from which we can analyze particular aspects of teachers' unions: the issues of class position in an extremely diversified category; the articulation among teachers' intellectual capabilities, issues related to professional autonomy, and political engagement; the ambivalent character of teachers' work in the middle of the way between social reproduction and transformation; the immaterial nature of teachers' work and its intervention in the formation of the work force; the bureaucratization of union structures and ways of domination in the movements and collective associations of the category, among others. Finally, the author calls attention to the lack of empirical studies on teachers' union based on consistent theoretical assumption, which would allow the analysis of the observed reality through the insertion on the totality of the global system.

In a work presented in the same event, Julián Gindin (2009) indicates some tendencies from the analysis of 89 theses and dissertations defended in Brazilian postgraduation programs until 2009, in which the following themes and methods of analysis are highlighted: (i) the study of unions' organization process, that is, a focus on the processes of institutionalization of teachers' movements, but also on the movement itself, be it the study on the genesis of unions, or the analysis of particular aspects of the category's fight, such as strikes; (ii) the impacts of

\footnotetext{
12 The first meeting was held in the Instituto Universitário de Pesquisa do Rio de Janeiro (Iuperj), on April 2009. Other regular meetings followed. The VI meeting which took place in Curitiba, in 2017, shows the strengthening of the network.
} 


\section{pro.posıções}

http://dx.doi.org/10.1590/1980-6248-2018-0013

$e$-ISSN 1980-6248

union fight in the political education of its associates, considering the union as a space of selfformation and an instrument of regulation of teachers' identity construction (political, profession, and collective); (iii) the repercussion of the political fights in the democratization of school management and the organization of teachers' work in public schools; (iv) the concepts and representations shared by union leaders and activist regarding teachers' work; (v) the gender mark in the constitution of the ways of participation and representation of teachers' work and political engagement; (vi) comparative studies on the theme.

As observed by the author (Gindin, 2009), most of this production is still unpublished. Another characteristic pointed by him is that most are the result of studies from researchers connected to themes related to their union-political experience, what would explain, at least partially, the activist quality of a great part of the production. Related to the studies of teachers' union, the author still perceived a predominance of dissertations and theses that, in some cases, could be considered as memories of regionally founding union experiences, as well as those that approach questions connected to the political debate originated in the unions, such as the issues of teachers' social origins. Regarding the time frame, Gindin (2009)shows that there is a significant number of theses and dissertations published in the 1980s focusing on the process of institutionalization of teachers' unions in different Brazilian states.

Even though the contributions we highlighted from the works of Dal Rosso and Gindin were formulated in 2009 , that is, ten years ago, we think that they are still relevant, as the theme is closely connected to the sharing of utopias related to career and society, and the belief on the constructive role of union fights. As already established, it is very common that the studies developed in this theme are done by researchers that have experienced union fights, adding to their research a place of speech that interconnects the affective memory and the desire of intervene in the debate. 


\section{pro.posıções}

http://dx.doi.org/10.1590/1980-6248-2018-0013

$e$-ISSN 1980-6248

If this involvement brings advantages to the proposed analysis, as the researcher personally knows the object of study, this same involvement can also interfere in a more rational and comprehensive observation, as it mixes the identities of researchers and object researched, calling the attention, once more, to the negotiation of identities that permeate the teaching profession.

\section{Issues to conclude: unionism and teachers' identities}

During our research (Xavier, 2012), it was possible to prove hypotheses and suggest interpretations regarding the role of associativism in the process of teachers' professionalization, analyzing its influence in the configuration of new professional identities and the boosting towards career mobility, as well as the configuration on a field of knowledge recognized internally (among peers) and externally (by the government and the society as a whole).

Nóvoa (1987) claims that teachers' associativism would express a crucial requirement in the process of teachers' professionalization can be nuanced. If this claim is true, the history of teachers' associativism in Brazil, particularly in the 1970s-80s, has shown more than the formation of an identity and agendas of common fights, but also conditions that, in our opinion, would mark the professional self-awareness. Beyond this, the repercussion of fights led by the unions at the time shed a light onto intense conflicts that emerged on the search of a common identity among teachers. Oscillating among teaching professionals, specialists/preachers of school knowledge, opinion makers, and transformative political dispositions, among many other images that could represent these professions, it was not possible, at the time and still today, to have expressive and durable consensuses. In fact, authors such as Vianna (1999) and Ferreira (2006) had already approached this theme in their studies, bringing relevant contributions to the debate.

Cláudia Vianna (1999) analyzes the issue of collective participation of public-school teachers in São Paulo in the frame of studies about collective action and gender relations. After interviewing several teachers, the author presented a mixture of postures and concepts on teachers' collective actions, helping us to understand the identities built and reconfigured in the influx of the crisis and the perspectives of teachers' collective actions in the 1990s. Thus, she ends up with four "types" of relations with collective action, that are: (i) the one identified with 


\section{pro.posições}

$e$-ISSN 1980-6248

http://dx.doi.org/10.1590/1980-6248-2018-0013

union militance; (ii) the one with a timely participation in big revindications and/or public demonstrations of the category; (iii) the collective action understood as dedication to the work done in school, not excluding the union, but opting to focus the energy on school work and not in a union militance; (iv) and, finally, the author identifies a group of teachers with no personal or social project regarding the profession and who did not believe in the benefits reached by collective mobilization.

In our opinion, this approach incites us to face the subsequent issue: how are teachers dealing - individually and collectively, spontaneously or organized- with the fragmentation and diversity that distinguish their professional identities? Certainly, the actions, the movements, and associative organizations also establish changes on teachers' professional identities. In the case of teachers' unions, they try to influence so as to promote an engagement in the political fights of the time, going beyond those pertinent to the professional careers. There is a dispute between the identity markers that approximate the model of liberal professional, understood by as those with an intellectual job, and the markers that identify them with the identity of educational workers, that is, those that define themselves as work power, exposed to exploitation, but with a consciousness that aligns them to the workers' fight for their professional emancipation and autonomy. This dispute between two identity patterns marked the 1970s-80s and is still current, as shown by Ferreira (2006).

Reflecting on the option of a proletarian identity, we can infer the image of proletarian can live with other identities, as well as the desire for professionalization, what shows that these identities are not necessarily exclusive, even if involving a certain ambiguity. What is at stake, as observed by Claude Dubar (2005), are the dynamics of identity negotiation. Such dynamics involve interaction with institutions and associations with the peers, the students, the school managers, as well as other desired identities. The game is complex and fluid, but extremely important to understand the role of union and professional associations, for example, in the creation of engaged and autonomous identities.

We conclude, for now, highlighting that the study of teachers' associativism can benefit from the knowledge created in a variety of studies. Beside the researches that we, in the field of education, develop and beyond them, are the open possibilities of interdisciplinary dialogue. As 


\section{pro.posições}

http://dx.doi.org/10.1590/1980-6248-2018-0013

$e-$ ISSN 1980-6248

can be seen in the studies presented in this article- the theoretical and the empirical ones - with each issue or ensemble of issues new references are mobilized, allowing for new approaches and producing new interpretations to the classic object of study in education, which refers to the protagonism of teachers in the fight for professional affirmation and in favor of the democratization of knowledge. We highlighted in this article the results of some of our researches, some possible paths, built on the dialogue with the other studies here mentioned that we would like to share with other people interested in the topic.

\section{References}

Adorno, T. (1995). Tabus acerca do magistério. In Educação e emancipação (W. L. Maar, trad., pp. 97-118). Rio de Janeiro: Paz e Terra.

Andrade, M. S. (2017). O sindicato como espaço de formação: Trajetórias de professores militantes do Sepe/Caxias. Tese de Doutorado, Pontifícia Universidade Católica do Rio de Janeiro, Rio de Janeiro.

Avritzer, L., \& Costa, S. (2004). Teoria crítica, democracia e esfera pública: Concepções e usos na América Latina. Dados, 47(4), 703-728. Recuperado de http:/ /www.scielo.br/scielo.php?pid=S0011$52582004000400003 \&$ script $=$ sci_abstract\&tlng $=$ pt

Braga, R. M. S. (2017). Nós as saudamos, professoras fluminenses: Produção, circulação e representações de professoras primárias no jornal Sintese da UPPE. Tese de Doutorado, Universidade do Estado do Rio de Janeiro, Rio de Janeiro.

Cerezales, D. P. (2003). O poder caiu na rua: Crise de Estado e ações coletivas na Revolução Portuguesa (1974-1975). Lisboa: ICS.

Dal Rosso, S. (2009). Sociologia e sindicalismo docente no Brasil. In Anais do I Seminário para Discussão de Pesquisas e Constituição de Rede Internacional de Pesquisadores: Associativismo e sindicalismo docente no Brasil (pp. 1-14). Rio de Janeiro: Iuperj. 


\section{pro.posições}

http://dx.doi.org/10.1590/1980-6248-2018-0013

$e-$ ISSN 1980-6248

Dubar, C. (2005). A socialização. São Paulo: Martins Fontes.

Ferreira, A.; \& Bittar, M. (2006). Proletarização e sindicalismo de professores na ditadura militar (19641985). São Paulo: Pulsar.

Ferreira, M. O. V. (2006). Somos todos trabalhadores em educação? Reflexões sobre identidades docentes desde a perspectiva de sindicalistas. Educaşão e Pesquisa, 32(2), 225-240. Recuperado de http://www.scielo.br/pdf/ep/v32n2/a02v32n2

Gindin, J. (2009). Os estudos sobre sindicalismo docente na América Latina e no Brasil. In Anais do I Seminário para Discussão e Constituição da Rede Internacional de Pesquisadores. Rio de Janeiro: Iuperj.

Gohn, M. G. (2008). Teorias dos movimentos sociais: Paradigmas clássicos e contemporâneos. São Paulo: Loyola.

Hobsbawm, E. J. (1982). Revolucionários. Rio de Janeiro: Paz e Terra.

Hobsbawm, E. J. (1987). Mundos do trabalho. Rio de Janeiro: Paz e Terra.

Lawn, M. (2001). Os professores e a fabricação de identidades. Currículo sem Fronteiras, 1(2), 117 130.

Lélis, I., \& Xavier, L. (2010). The teaching profession in the voice of its union leaders. Sísifo: Educational Sciences Journal, 11, 24-35.

Lemos, D. (2011). Professores em movimento: A emergência do associativismo docente na Corte Imperial. Tese de Doutorado, Universidade Federal de Minas Gerais, Belo Horizonte. Recuperado de https://repositorio.ufmg.br/bitstream/1843/BUOS8GHNHU/1/tese_daniel_c._de_a._lemos.pdf

McAdam, D., Tarrow, S., \& Till, C. (2009). Para mapear o confronto político. Lua Nova, 76, 11 48. Recuperado de http://www.scielo.br/pdf/ln/n76/n76a02.pdf

Nóvoa, A. (1987). Le temps des professeurs: Analyse socio-historique de la profession enseignante au Portugal (XVIII-XX siècle) (Vols. 1-2). Lisboa: Instituto Nacional de Investigação Científica.

Perruso, M. A. (2009). Em busca do "novo": Intelectuais brasileiros e movimentos populares nos anos 19701980. São Paulo: Annablume.

Revel, J. (Org.). (1998). Jogos de escalas: A experiência da microanálise. Rio de Janeiro: FGV. 


\section{pro.posıções \\ rassmenam}

http://dx.doi.org/10.1590/1980-6248-2018-0013

Rioux, J.-P. (1996). A associação em política. In R. Remond, Por uma bistória política (pp. 99-140). Rio de Janeiro: FGV.

Tilly, C. (1977). From mobilization to revolution. Ann Arbor: University of Michigan. https://deepblue.lib.umich.edu/bitstream/handle/2027.42/50931/156.pdf

Vianna, C. (1999). Os nós do nós: Crise e perspectiva de ação coletiva docente em São Paulo. São Paulo: Xamã.

Vicentini, P. P., \& Lugli, R. G. (2009). História da profissão docente no Brasil: Representações em disputa. São Paulo: Cortez.

Xavier, L. (2011). Ação coletiva, oportunidade política e identidade docente nos jogos de poder: Um ensaio a partir dos movimentos docentes brasileiro e português. In S. Dal Rosso (Org.), Associativismo e sindicalismo em educação (pp. 191-209). Brasília, DF: Paralelo.

Xavier, L. (2012). A profissão docente em contextos de transição democrática: Brasil e Portugal 1970-80. In S. C. Lopes, \& M. W. Chaves (Orgs.), A história da educaşão em debate: estudos comparados, profissão docente, familia e igreja (1 ${ }^{\text {a }}$ ed., Vol. 1, p. 229-255). Rio de Janeiro: Mauad.

Xavier, L. (2013a). Associativismo docente e construção democrática: Brasil-Portugal (1950-1980). Rio de Janeiro: Eduerj - Faperj.

Xavier, L. (2013b). Os movimentos docentes brasileiro e português na virada dos anos 197080. Tempo e Argumento, 5(10), 234-257.

Xavier, L. (2014). Trajetórias profissionais de professores em contextos de transição democrática. In J. Pintassilgo (Org.). O 25 de abril e a educação: Discursos, práticas e memórias docentes (Vol. 1, p. 149-166). Lisboa: Colibri.

Submitted for evaluation in April 3rd, 2018; revised in June $7^{\text {th }}$, 2018; accepted for publication in June 13th, 2018. 